\title{
BOISSONNAT (Jean), GRANNEC (Christophe), L'Aventure du christianisme social
}

Paris, Bayard-Desclée de Brouwer, 1999, 156 p. (bibliogr., illustr.)

Corinne Valasik

\section{OpenEdition}

\section{Journals}

Édition électronique

URL : http://journals.openedition.org/assr/20385

DOI : $10.4000 /$ assr. 20385

ISSN : $1777-5825$

Éditeur

Éditions de l'EHESS

Édition imprimée

Date de publication : 31 décembre 2000

Pagination : 143

ISBN : 2-222-96698-1

ISSN : 0335-5985

\section{Référence électronique}

Corinne Valasik, «BOISSONNAT (Jean), GRANNEC (Christophe), L'Aventure du christianisme social »,

Archives de sciences sociales des religions [En ligne], 112 I octobre-décembre 2000, document 112.62,

mis en ligne le 19 août 2009, consulté le 21 septembre 2020. URL : http://journals.openedition.org/ assr/20385; DOI : https://doi.org/10.4000/assr.20385

Ce document a été généré automatiquement le 21 septembre 2020

(C) Archives de sciences sociales des religions 


\section{BOISSONNAT (Jean), GRANNEC (Christophe), L'Aventure du christianisme social}

Paris, Bayard-Desclée de Brouwer, 1999, 156 p. (bibliogr., illustr.)

\section{Corinne Valasik}

\section{RÉFÉRENCE}

BOISSONNAT (Jean), GRANNEC (Christophe), L'Aventure du christianisme social,Paris, Bayard-Desclée de Brouwer, 1999, 156 p. (bibliogr., illustr.)

1 Co-écrit par le président des Semaines Sociales de France, J.B. (les Semaines Sociales de France, d'inspiration catholique, réfléchissent depuis près d'un siècle aux questions sociales de la société) et un historien, C.G., cet ouvrage se compose de deux parties. L'une, historique, brosse à grands traits l'évolution du christianisme social de ses origines à nos jours tout en mettant en avant l'apport spécifique des chrétiens à la pensée sociale. Remontant aux débuts du christianisme, J.B. quant à lui expose l'ensemble des positions prises par les chrétiens concernant les problèmes politiques et sociaux. Il n'oublie pas de mentionner les conflits qui en ont résulté avec le reste de la société. Fort de cette mise en perspective, ce catholique engagé encourage les chrétiens dans la voie d'une «laïcité-dialogue ». L'ouvrage s'achève sur un dialogue avec le $\mathrm{P}$. Henri Madelin à propos des encycliques sociales depuis Rerum Novarum.

2 Agrémenté de photographies de personnalités, ce livre joue son rôle pédagogique en présentant les grandes étapes du catholicisme social, pensée souvent considérée dépassée. 